Supplement of Hydrol. Earth Syst. Sci., 24, 5453-5472, 2020

https://doi.org/10.5194/hess-24-5453-2020-supplement

(C) Author(s) 2020. This work is distributed under

the Creative Commons Attribution 4.0 License.

(c) (1)

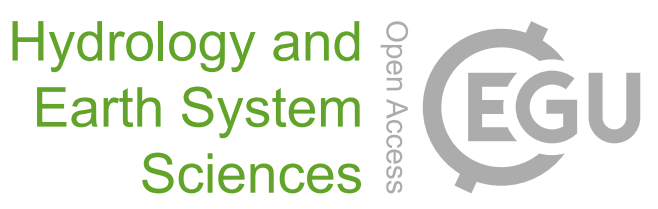

Supplement of

\title{
Predicting probabilities of streamflow intermittency across a temperate mesoscale catchment
}

Nils Hinrich Kaplan et al.

Correspondence to: Nils Hinrich Kaplan (nils.kaplan@hydrology.uni-freiburg.de)

The copyright of individual parts of the supplement might differ from the CC BY 4.0 License. 


\section{Supplement}

10 S1 Soil maps

Spatial information on soils is obtained from homogenized soil maps of Luxembourg and Belgium (Table S1). Available data includes information on soil texture, drainage behaviour and soil profile (Table S2). Soil texture in the initial data source was grouped into different texture sets (j, Table 3) each holding up to 6 different texture classes. Values of saturated hydraulic 15 conductivity $\left(K_{S}\right)$ and field capacity $\left(\theta_{a}\right)$ were derived by pedotransfer functions from Carsel and Parrish (1988) for each texture class. Average $K_{s}$ and $\theta_{a}$ were calculated as $\bar{K}_{s, j}$ and $\bar{\theta}_{a, j}$ for each set of texture classes $(j)$. The drainage information comprises 4 different classes including the categories "very well drained", "well drained", "moderately drained" and "poorly drained".

A class specific $K_{s}$ and $\theta_{a}$ was assigned to each drainage class of a texture set. We used the maximum $K_{S}$ of the matrix texture

20 within a texture set for the drainage class "very well drained" and the minimum Ks of the matrix texture for the drainage class "poorly drained". Accordingly we assigned the minimum $\theta_{a}$ within a texture set to the "very well drained" drainage class and the maximum $\theta_{a}$ within a set to the "poorly drained" drainage class. Classes Values of $\bar{K}_{s, j}$ and $\bar{\theta}_{a, j}$. were assigned to the "moderate and imperfect" drainage subclass. $K_{s}$ for the class of "well drained" were calculated for each matrix texture subclass from the maximum and the average of the subclass $j$ as:

$25\left(\max \left(K_{s, j}\right)+\bar{K}_{s, j}\right) / 2$

Hence, we calculated the $\theta_{a}$ for "well drained" as the average of minimum $\theta_{a}$ and the $\bar{\theta}_{a, j}$.of a texture set: $\left(\min \left(\theta_{a, j}\right)+\bar{\theta}_{a, j}\right) / 2$

The profile class was included as a horizon-correction factor to adjust the values to the measured effective hydraulic conductivities. For the horizon-correction we assume that soils with B-horizon drain slightly better than soils with Bt-horizon 
and therefore have assigned a higher effective hydraulic conductivity. This assumption is based on unpublished field measurements from the CAOS research group (Catchments as Organized Systems, see. e.g. Zehe et al., 2014) which revealed the differences between identical soil classes having either B horizons or Bt horizons. Although studies focusing on alteration of hydraulic conductivity with clay illuviation in Bt horizons are rare the assumption is supported by several studies (e.g.

5 Alletto et al., 2006; Coquet et al., 2005; Ferrer Julià et al., 2004; Lavkulich and Arocena, 2011). Based on the available soil data from the Attert catchment soils without B/Bt-horizon are assumed to have the poorest drainage and therefore a lower hydraulic conductivity (Table S2). Including the horizon correction and drainage classes the calculated hydraulic conductivity is able to represent the order of magnitude found from field measurements of the saturated hydraulic conductivities $K_{s, e f}$ measured by the CAOS research group. Following the assumptions for the $K_{s}$ we included slight correction factors for $\theta_{a}$ 10 accounting for the presence or absence of the B/Bt-horizons.

Values for all permutations of subclasses (Table S2) of $K_{s}$ as well as of $\theta_{a}$ were calculated and mapped in raster format using ArcGIS resulting in predictor maps for $K_{s}$ and $\theta_{a}$. Catchment average values were calculated for $K_{s}$ as well as for $\theta_{a}$ using Eq. 3. Some of the calculated $K_{s}$ class permutation could be validated with the 400 soil texture and $K_{s, e f}$ data available from the CAOS research group and were well within the range of the validation data. However, the validation data for many classes contained only a small number of measurements and thus show a high deviation of measured values.

Table S1: References for all soil maps that have been homogenized for the Attert basin.

\begin{tabular}{l|ll} 
Country & Scale & Reference \\
\hline Belgium & $1: 20,000$ & Public Service of Wallonie, 2007 \\
Luxembourg & $1: 25,000$ & Wagener et al. 1971, 1972, 1975; Puraye et al., 1980, 1988, 1995, 1998 \\
& $1: 50,000$ & Vermeire, 1967 \\
& $1: 100,000$ & Wagener et al., 1969
\end{tabular}


Table S2: Soil classification of the homogenized soil map for the Attert basin. Classes have been joined from sources in Table S1.

\begin{tabular}{|c|c|c|c|c|}
\hline Class & $\begin{array}{l}\text { Sub- } \\
\text { class/Set }\end{array}$ & Soil Textures within a set & $\bar{K}_{s, j} \cdot[\mathrm{cm} / \mathrm{d}]$ & $\bar{\theta}_{a, j}[\mathrm{~mm}]$ \\
\hline \multirow{13}{*}{$\begin{array}{l}\text { Matrix } \\
\text { Texture } j\end{array}$} & A & silty soils, textural classes silt, Silt & \multirow{2}{*}{38.45} & \multirow{2}{*}{255} \\
\hline & & loam,silt clay loam & & \\
\hline & \multirow[t]{3}{*}{$\mathrm{G}$} & gravelly soils with matrix textural class & \multirow{3}{*}{79.40} & \multirow{3}{*}{198} \\
\hline & & silt,silt loam, loam, loam, clay loam, silt & & \\
\hline & & clay loam, sandy clay loam, sandy loam & & \\
\hline & $\mathrm{L}$ & sandy-loamy soils, textural classes sandy & \multirow{2}{*}{140.60} & \multirow{2}{*}{180} \\
\hline & & loam, loam, silt loam & & \\
\hline & $\mathrm{S}$ & loamy-sandy soils, textural classes loamy & \multirow{2}{*}{825.12} & \multirow{2}{*}{54} \\
\hline & & sand, sandy loam & & \\
\hline & $\mathrm{U}$ & clayey soils, textural classes sandy clay, & \multirow{2}{*}{12.91} & \multirow{2}{*}{116} \\
\hline & & clay, silty clay & & \\
\hline & $\mathrm{V}$ & peat soils & 825.12 & 54 \\
\hline & & & \multicolumn{2}{|c|}{ Value selection } \\
\hline \multirow[t]{4}{*}{ Drainage } & B & very well drained & $\max \left(K_{s, j}\right)$ & $\min \left(\theta_{a, j}\right)$ \\
\hline & $\mathrm{b}$ & well drained & $\left(\max \left(K_{s, j}\right)+\bar{K}_{s, j}\right) / 2$ & $\left(\min \left(\theta_{a, j}\right)+\bar{\theta}_{a, j}\right) / 2$ \\
\hline & $\mathrm{D}$ & moderately drained & $\bar{K}_{s, j}$ & $\bar{\theta}_{a, j}$ \\
\hline & I & poorly drained & $\min \left(K_{s, j}\right)$ & $\max \left(\theta_{a, j}\right)$ \\
\hline
\end{tabular}

Horizon-Correction

Factor

Correction Factor

\begin{tabular}{llcrr}
\hline Profile & $\mathrm{a}$ & with Bt horizon & 0.5 & 1.2 \\
& $\mathrm{~b}$ & with B horizon & 1 & 1.0 \\
$\mathrm{~B}$ & with either B and/or Bt horizons & 0.75 & 1.1 \\
& $\mathrm{p}$ & without B horizon & 0.5 & 0.8
\end{tabular}


(a)

\section{Legend}

- Soil Samples

\section{Hydraulic Conductivity}

[cm/d]

27
0

2701.44

8

8

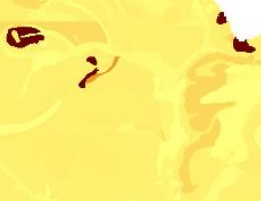

$\odot$
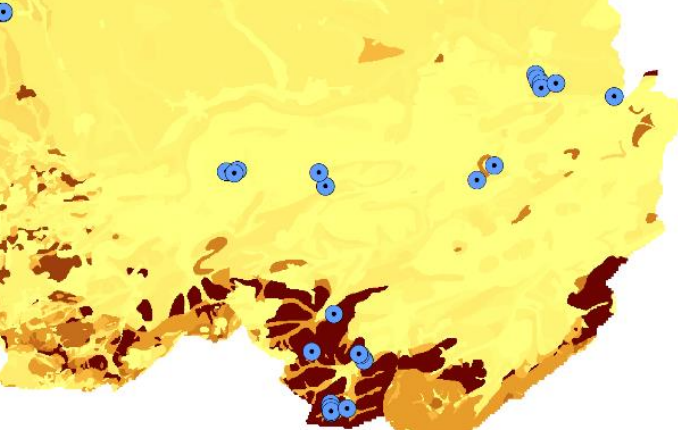

(b)

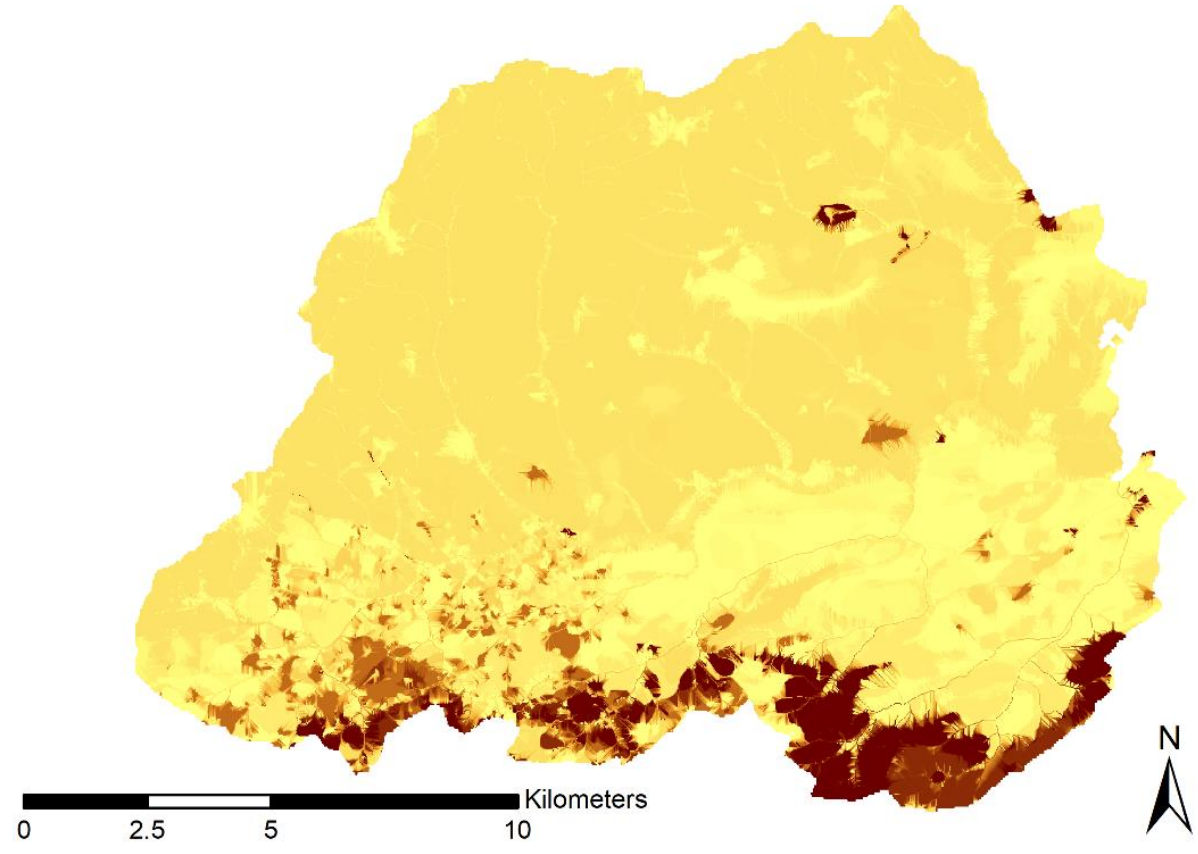

Figure S1: The hydraulic conductivity map (a) was derived from the homogenized soil maps by the procedure described in this supplement. Soil sample sites from the CAOS (Catchment As Organized Systems) soil data base are also shown in (a). This data set comprises 400 sampling sites. The upslope area averages of the hydraulic conductivity are shown in (b). 


\section{S2 Precipitation distribution in the Attert catchment}

Spatial variability of precipitation is not a major control in the Attert catchment. Figure S2 shows the spatial distribution of precipitation for the modelled time periods. Figure S3 shows the local precipitation at the measurement points plotted against the local residuals of the statistical models.

(a)

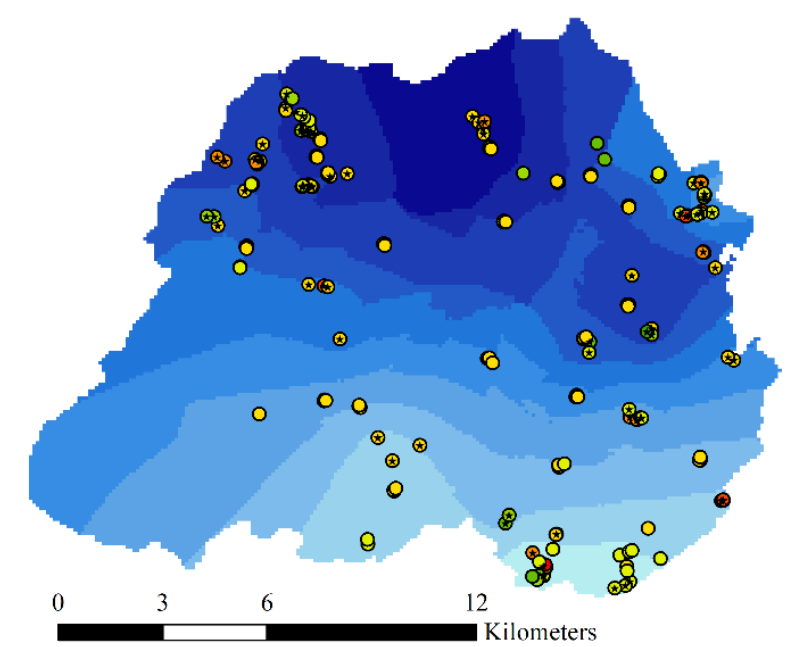

* Local Precipitation Data Precipitation

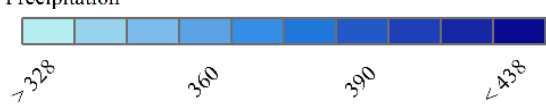

Deviation Observed vs. Modelled Intermittency

(b)

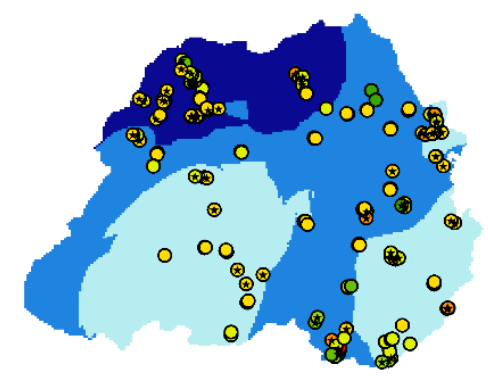

(c)
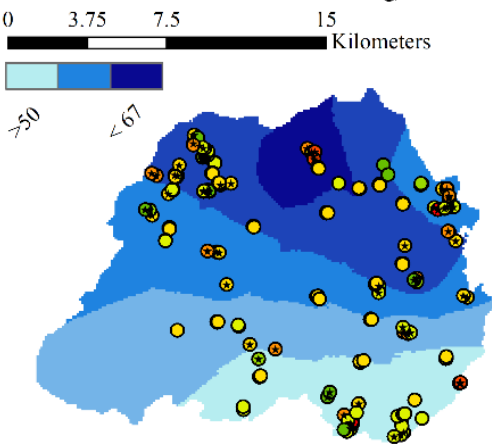
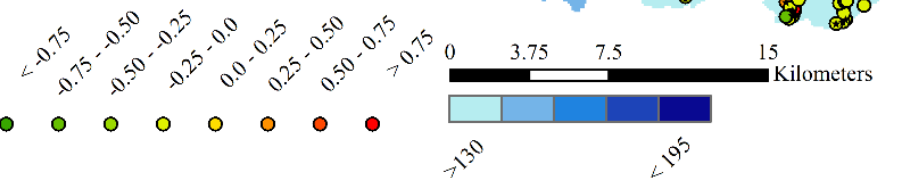

5

Figure S2: Cumulative Precipitation distribution in the Attert catchment for the annual period July 2016 to July 2017 (a), the wet period (February to April, (b)) and dry period (June to August, (c)). Note: wet and dry here refers to discharge, not to rainfall input. Precipitation data is interpolated with ordinary kriging from site specific local precipitation data (black stars). Precipitation data was provided from a precipitation modelling approach by Neuper \& Ehret (2019) which combines weather radar and ground-based precipitation data. The deviation between observed and modelled intermittency is plotted for the corresponding periods. 

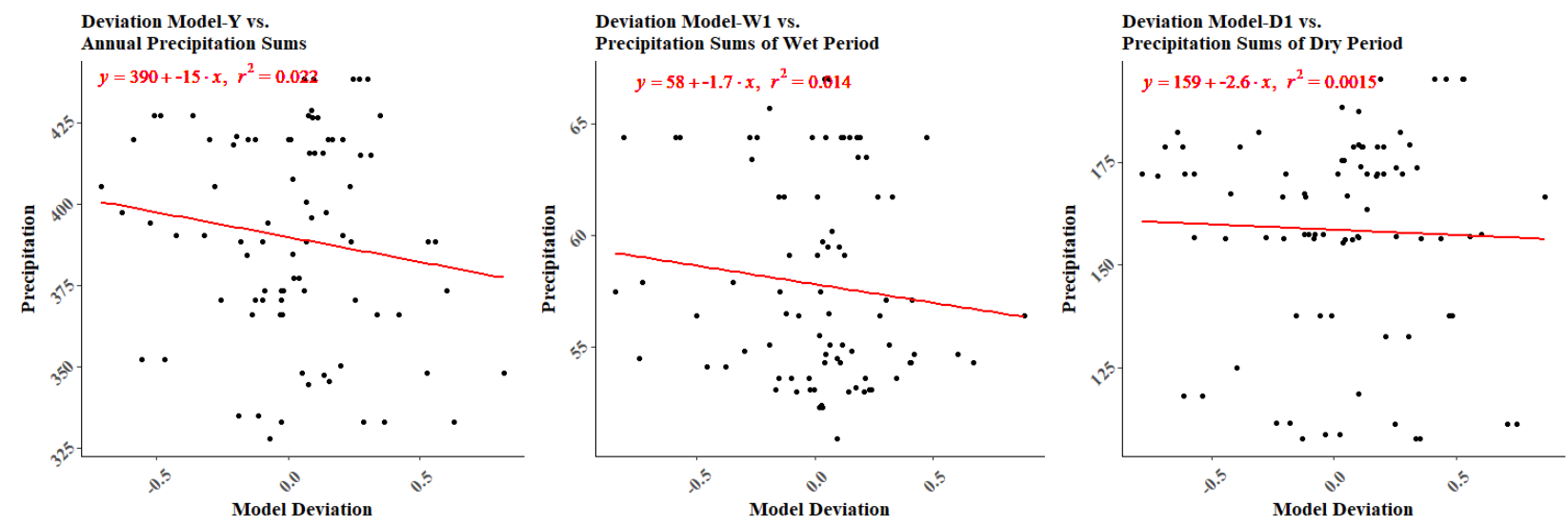

Figure S3: Deviation between observed and modelled plotted against the corresponding precipitation sums of the modeled periods. 


\section{References}

Alletto L., Coquet Y., Vachier P. and Labat C.: Hydraulic Conductivity, Immobile Water Content, and Exchange Coefficient in Three Soil Profiles. Soil Sci. Soc. Am. J. 70, 1272-1280, doi:10.2136/sssaj2005.0291, 2006.

5

Coquet Y., Vachier P. and Labat C.: Vertical variation of near-saturated hydraulic conductivity in three soil profiles. Geoderma 126, 181-191, doi:10.1016/j.geoderma.2004.09.014, 2005.

Lavkulich L.M. and Arocena J.M.: Luvicolic soils of Canada: Genesis, distribution, and classification. Can. J. Soil Sci. 91, 10 781-806, doi:10.4141/CJSS2011-014, 2011.

Public Service of Wallonie: Service public de Wallonie, Département de la Géomatique, Pedological Map of Wallonie, Belgium, 1:20.000, Faculté universitaire des Sciences agronomiques de Gembloux, Gembloux, Wallonie, Belgium, 2007.

15 Ferrer Julià M., Estreala Monreal T., Sánchez del Corral Jiménez A. and García Meléndez E.: Constructing a saturated hydraulic conductivity map of Spain using pedotransfer functions and spatial prediction. Geoderma 123, 257-277, doi:10.1016/j.geoderma.2004.02.011, 2004.

Neuper M. and Ehret U.: Quantitative precipitation estimation with weather radar using a data- and information-based approach. Hydrol. Earth Syst. Sci., 23, 3711-3733, https://doi.org/10.5194/hess-23-3711-2019, 2019.

Puraye A., Schaack A. and Faltz N.: Carte des sols du Grand-Duché de Luxembourg, 1:25.000. Feuille 4 - Esch-sur-Sûre. Ministère de l'Agriculture, de la Viticulture et des Eaux et Forêts, Administration des Services Techniques de l'Agriculture, Service de Pédologie, Ettelbruck, 1980.

25

Puraye A., Schaack A. and Faltz N.: Carte des sols du Grand-Duché de Luxembourg, 1:25.000. Feuille 9 - Echternach. Ministère de l'Agriculture et de la Viticulture, Administration des Services Techniques de l'Agriculture, Service de Pédologie, Ettelbruck, 1988.

30 Puraye A., Schaack A. and Faltz N.: Carte des sols du Grand-Duché de Luxembourg, 1:25.000. Feuille 6 - Beaufort. Ministère de l'Agriculture et de la Viticulture, Administration des Services Techniques de l'Agriculture, Service de Pédologie, Ettelbruck, 1995. 
Puraye A., Schaack A. and Faltz N.: Carte des sols du Grand-Duché de Luxembourg, 1:25.000. Feuille 13 - Remich. Ministère de l'Agriculture et de la Viticulture, Administration des Services Techniques de l'Agriculture, Service de Pédologie, Ettelbruck, 1998.

5 Vermeire, R.: Oppervlaktegeologie en bodemgesteldheid van het westelijk Gutland (Groot-Hertogdom Luxemburg), Thèse de doctorat, Rijksuniversitéit Gent, Faculteit der Wetenschappen, 1967.

Wagener J. and Schaack A.: Carte des sols du Grand-Duché de Luxembourg, 1:25.000. Feuille 10 - Luxembourg. Ministère de l'Agriculture et de la Viticulture, Administration des Services Techniques de l'Agriculture, Service de Pédologie,

10 Ettelbruck, 1971.

Wagener J. and Schaack A.: Carte des sols du Grand-Duché de Luxembourg, 1:25.000. Feuille 1 - Troisvierges. Ministère de l'Agriculture et de la Viticulture, Administration des Services Techniques de l'Agriculture, Service de Pédologie, Ettelbruck, 1972.

15

Wagener J., Schaack A. and Faltz N.: Carte des sols du Grand-Duché de Luxembourg, 1:25.000. Feuille 12 - Esch-sur-Alzette. Ministère de l'Agriculture et de la Viticulture, Administration des Services Techniques de l'Agriculture, Service de Pédologie, Ettelbruck, 1975.

20 Wagener J., Vermeire R, Schaack A.: Carte des sols du Grand-Duché de Luxembourg, 1:100.000. Ministère de l'Agriculture et de la Viticulture, Administration des Services Techniques de l'Agriculture, Service de Pédologie, Ettelbruck, 1969. 